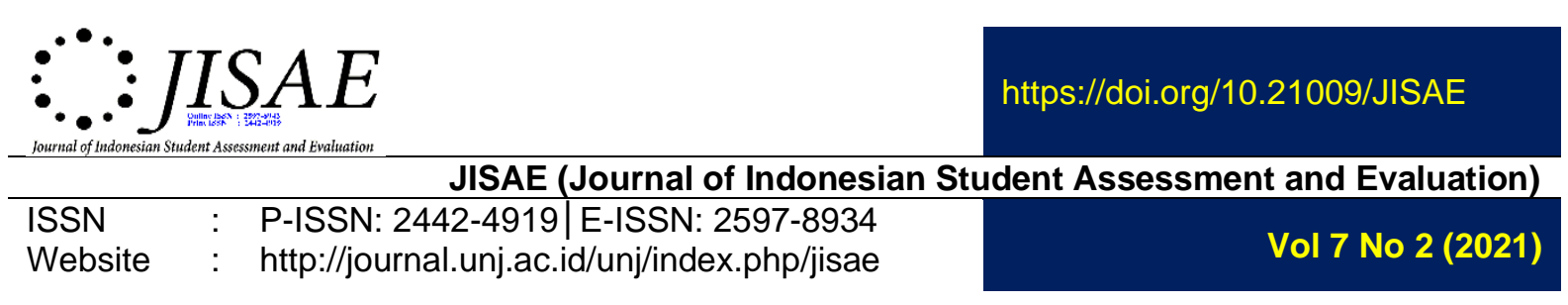

\title{
EVALUATION OF TEACHING SKILL PRACTICE PROGRAMS, IN THE STATE UNIVERSITY EDUCATION DEVELOPMENT \\ INSTITUTION JAKARTA
}

Bambang Afriadi ${ }^{1}$, Agus Dudung ${ }^{2}$

\begin{abstract}
The purpose of this study is to describe the Program Practice Skills Teaching (PKM/ Praktik Keterampilan Mengajar) in semester 106, at the Educational Development Institute State University of Jakarta. The evaluation model used in this study is a formative and summative evaluation model developed by Michele Shriven. Formative evaluation is carried out during the program to provide information to the program leader as program improvement materials. While the summative evaluation is done at the end of the program. This research use evaluation analysis with qualitative and quantitative approach. How to collect data on this evaluation research is using techniques observation, questionnaires, interviews, and documentation. The results showed that in the formative evaluation, it can be seen that in general the process of Program PKM was by existing guidelines. So can be maintained the existence of the PKM Program. While the results of the summative evaluation showed that the PKM Program, in the high category, is based on the value of the minimum PKM Program participants B provided by the teacher mentor and lecturer mentor of the final exam.
\end{abstract}

Universitas Islam Syekh Yusuf ${ }^{1}$, Universitas Negeri Jakarta ${ }^{2}$.

bambang.afriadi@unis.ac.id ${ }^{1}$. agusdudung65@gmail.com ${ }^{2}$

Keywords: Evaluation of Teaching Skills Practice

Program, Formative Evaluation Model, and Summative Evaluation Model

\section{INTRODUCTION}

Field Experience Program (PPL/Program Pengalaman Lapangan) courses in the S-I Study Program since the 2010/2011 academic year renamed the Pratik Teaching Skills (PKM/ Praktik Keterampilan Mengajar) course with a weight of 2 credits. This change was motivated by Law No. 14 of 2005 concerning Teachers and Lecturers and Government Regulation No. 74 of 2009 concerning the Professional Teachers' Professional Education Program, which states that teachers are professional positions who are required to have academic quality with a minimum S-1 / D-IV education certificate and have an education certificate through professional education.

Professional education in question is Teacher Professional Education (PPG) based on Permendiknas No. 9 of 2010. Consists of several activities in the form of workshops and Field Experience Programs (PPL). To support the competence of education college students as prospective teachers, it is necessary to plan one practical course in the S-1 education study program, namely Pratik Teaching Skills (PKM/ Praktik Keterampilan Mengajar) courses. 
Pratik Teaching Skills (PKM// Praktik Keterampilan Mengajar) is a program that is a training arena to apply knowledge, attitudes, and skills for the formation of prospective teachers and professional education personnel. This program is to train college students to be responsible for carrying out tasks as prospective teachers who can arrange class administration along with the completeness of learning tools and the ability to carry out learning.

The Teaching Skills Practice Program (PKM) college students will be able to apply the existing theories by looking at the phenomena during the Teaching Skills (PKM) activities. In Pratik Teaching Skills (PKM) activities are held in school for 2 full days per week (according to schedule) for one semester (4 months). For this reason, several stages must be passed by PKM college students during this activity in partner schools. It is expected that college students can become someone who is professional and has the ability in their fields. Teaching exercises are teaching practice activities conducted by PKM college students and guided by 'GP' (Civil Teacher) and 'DP' (Supervisor). This teaching practice includes the preparation of classroom administration of Learning Implementation Plans (RPP) and learning tools, implementation of classroom learning, assessment of learning outcomes, and ending with the determination of student graduation. By conducting the Pratik Teaching Skills Program (PKM), college students are expected to be able to improve their competencies as prospective teachers, which include pedagogic competencies, professional competencies, personality competencies, and social competencies, as a provision for self-service in the teaching profession in the future. This teaching exercise ends with a PKM assessment by the mentor, which is an authentic and good assessment of authenticity. In this context, the teacher's competence can be interpreted as the unanimity of knowledge, skills, and attitudes that are manifested in a set of smart and responsible actions that a teacher has to assume the position of teacher as a professional.

The focus of the research on the evaluation process is expected to be useful for the development of the Pratik Skills Teaching program (PKM) at the UNJ Educational Development Institute. Evaluation is seen as a process of determining the results achieved by several activities planned to support the achievement of goals. Research in evaluating the Pratik Teaching Skills Program (PKM) at the Universitas Negeri Jakarta (UNJ) Educational Development Institute is to collect information about the implementation of the program, which in turn is used to determine the right alternative in making decisions.

\section{RESEARCH METHODS}

This study uses an evaluation analysis model with qualitative and quantitative methods. Through the qualitative approach, the data collected will be tried to be processed and presented in descriptions based on expressions, the language of the way of thinking, and views of subject research. Qualitative research is also used to uncover trends in thoughts and opinions, and dive deeper into problems. While quantitative research is used to measure problems by producing numerical data or data that can be converted into statistics that can be used. It is used to measure attitudes, opinions, behaviors, and other variables that are defined and generalize the results of a larger sample population.

\section{RESEARCH RESULT}

Based on the results of research from data from observations, interviews, document studies, and questionnaires. It was found that the implementation of Teaching Skills Practices from the dimensions of formative and summative evaluation 
models, included in the category both from the initial process of implementation to the end of the implementation of the results of the program assessment of teaching skills practice.

\section{A. Formative Evaluation}

a) Technical Preparation

Based on the results of the evaluation of the technical preparation of the Teaching Skills Practice Program. A letter of mechanism for the implementation of the Teaching Skills Practice Program has been issued. The main thing in the preparation of the program, from the evaluation results on the formative component shows the existence of a circular of the implementation of the PKM Program in the high category. This, it can be seen that all Faculties at UNJ receive and carry out the procedures of the circular letter.

Circular of Teaching Skills Practice Program, even semester (106) in 2016/2017. Explain the details of the registration time and the deadline for the registration of the PKM Program. The letter explains that the Head of Study Program informs that college student who has fulfilled the PKM requirements must immediately register themselves in their account through the website http://siakad.unj.ac.id/ according to the predetermined schedule. From the circular letter, it can be seen that the registration results of all PKM Program participants register online according to a circular letter.

The results of the evaluation of the Teaching Skills Practice Program in preparing formats (guidelines) to support the implementation of the PKM Program in the high category. The formats include the format of the Teachers' Assessment Assessment Tool, the minutes of the official report, the format of the attendance list of PKM college students, the format of the attendance list of the supervisors in the school, and the format of student summaries during PKM which must be filled by PKM participants and submitted a return to UPT PPL / PKL. These formats have been prepared and can be downloaded on the website http://unj.ac.id/lpp/ (Access 28 November 2016). The website also provided a Teaching Skills Practical handbook. So that college students are facilitated in having these formats for printing.

In implementing the PKM Program by the PPL/PKL Center (Center for Field Experience Program/Teaching Skills Practices) in PKM Program partner schools. Firstly coordinate with the head of the field/head of the Sub-Department of Primary and Secondary Education Services. Through Circular stating that the PPL / PKM Center in licensing implements a Teaching Skills Program in the area of the Primary and Secondary Education Office. The letter shows that coordination has been carried out to smooth the PKM Program to the Office of Primary and Secondary Education to implement the program.

The PPL / PKL center as readiness in the implementation of the PKM Program has prepared as many as 108 partner schools. Of the 7 faculties at UNJ, among others: Faculty of Education, Language and Arts Faculty, Faculty of Social Sciences, Faculty of Economics, Faculty of Engineering, Faculty of Mathematics and Natural Sciences, and Faculty of Sports Sciences. Of the 7 faculties, the college student was distributed to PKM Partner Schools as many as 180 PKM participants with 108 lecturers. This amount is from the results of the evaluation by the conditions in the field and the quota of PKM Participants. in this case, the PPL / PKL Center has prepared schools for the Teaching Skills Practice Program in the high category.

Collaboration with PUSTIKOM UNJ, as a center for managing the use of information technology and communication. PUSTIKOM UNJ supports PKM Program as a subject, in this case, PUSTIKOM provides input and management of PKM participant data. Storage and management of PKM data are sourced from a college student who 
registers through the siakadunj.ac.id website from the accounts owned by college students. In the evaluation results of this formative component, included in the high category. This can be seen from the structured and systematic management of the PKM Program implementation process.

b) Registration Procedure

The registration procedure as a student participant in the PKM Program is carried out by college students through the website http://siakad.unj.ac.id/. College student first input their student ID number and password. After logging in, the student enters his account. Then college students input the PKM course code on the Study Plan Card (KRS) 106. In the evaluation of the procedure at this stage in the PKM program. A college sststudentustudent who s the PKM Program is the only college student who meets the requirements. Requirements include undergraduate education college students who have passed courses at least 110 credits, in the previous semester and college students who have passed Basic Education Courses (MKDK), and have and have attended microteaching. If it does not meet the requirements, automatically college students who will enroll in the Teaching Skills Practice Program cannot input as PKM participants. Conversely, if it has fulfilled the requirements automatically when the input of PKM courses will be registered. This is because the names of the previous PKM participants have been submitted from the study programs through the Faculty PKM Program Coordinator to the PPL / PKL Center and verified at PUSTIKOM. So that the evaluation evaluation evaluation is included in the high category, supported by data that meets the criteria for the PKM program objectives.

c) Requirements for Student Participants in the PKM Program

To prepare college students to implement their knowledge and abilities during lectures, especially the Basic Education (MKDK) subjects. In the MKDK, 4 credits must be taken by all undergraduate education college students at the Jakarta State University who prepare their collegstudentsnt to become professional educators. After graduating from the course, before going to school. College students prioritize microteaching practices guided by lecturers. In this activity, college students conduct practical teaching simulations in class. Witnessed by fellow college students who were simulated as college students and assessed by lecturers. After conducting microteaching practices. A college student who has passed will be given a certificate. Conversely, if their air a college student who is declared as not passing, they will repeat the practice of microteaching until they are passed. As a standard requirement for joining the PKM Program, microteaching is the right activity. Especially has been well organized and systematic. If there are college students who have not yet passed the microteaching, the student is not submitted to join the PKM Program. in this case, it was verified in the UNJ Academy that data was submitted from each study program through each faculty and submitted to the UPT PPL / PKL to be submitted to PUSTIKOM. In the military evaluation, evaluation results are included in the high category from the results of an objective assessment of the existing and executed system.

d) Implementation of Teaching and Non-Teaching Skills Practices

In the assessment process, evaluation of the implementation of Teaching and NonTeaching Skills Practices by PKM participants in the high category. This is based on the results of assessments conducted in the field, both observations, and in-depth interviews with several tutors, and supported by the results of interviews with supervisors.

In the implementation of mega jar skills in school practice, it is known from the results of interviews with tutors to PKM participants. It was found that PKM participants 
proceeded. Process, in this case, shows the adaptation pattern or graph of the success of PKM participants in teaching practice. At the first time of teaching, it was found from the results of the tutor teacher's explanation that college students still needed to adapt in mastering the class and transferring the subject's eyes. After being guided several times by the tutor teacher, PKM participants were able to master and explore their abilities in the classroom. While for non-teaching activities. PKM participants, given the opportunity or involved such as being picket teachers, attending meetings, supervising examinations, and becoming national committees. So in this point, the results of this stage evaluation are stated in the high category. So that it can be concluded that the implementation of the PKM Program in school is by the goals and expectations of the program. There is no vocabulary in the implementation which means damaging the implementation of the program.

The PKM program can be analyzed using Talcott Parsons functional theory with four functional requirements of a system. For Talcott Parsons, a system can only be functional if all requirements are met. There are four functional requirements needed by a system, namely: adaptation / adaptation (A), goal attainment (G), integration / integration (I), and latent pattern maintenance / latent maintenance patterns (L). From the overall requirements of a system fulfilled it can be functional so that the goal will be achieved. From this theory can be known by the following scheme:

\section{Scheme 1.1}

\section{AGIL's Functional System in Implementing the PKM Program}

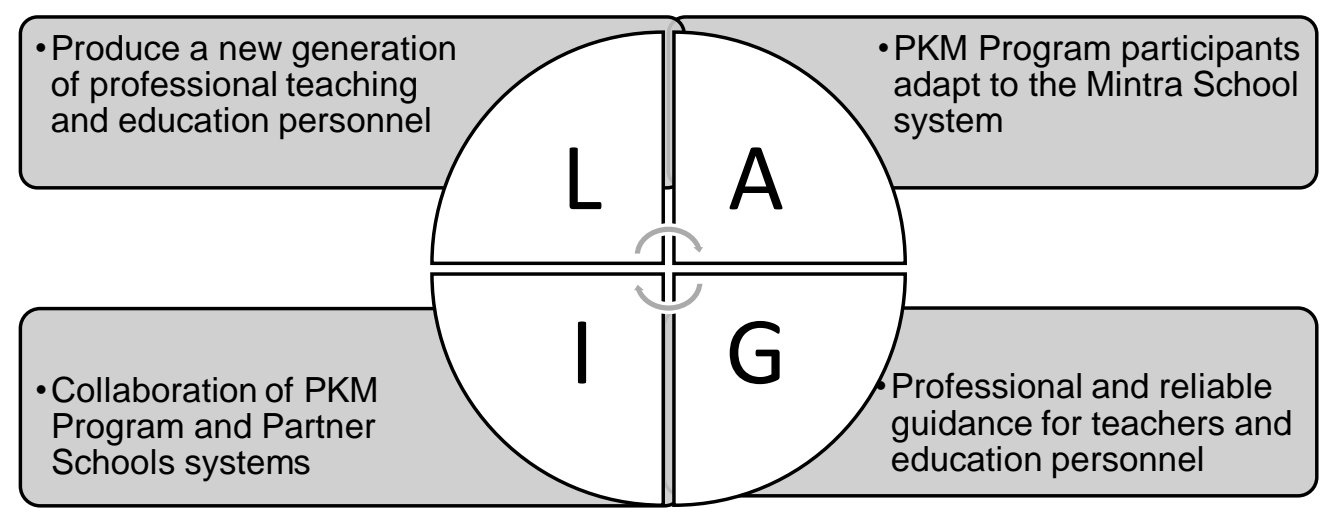

Results of the Researcher's Analysis

The above scheme for PKM Program activities carried out by PKM participants in PKM Partner Schools can be analyzed through these four conditions. First, the function of adaptation in the implementation of activities is needed. In the implementation of the PKM Program, as a condition of joining PKM, PKM participants have passed courses at least 110 SKS, in the previous semester, and college students have passed the Basic Education Subject (MKDK). The Basic Education Subjects (MKDK) include subjects of Learning and Learning Theory and Introduction to Educational Sciences. The two MKDKs weigh 4 Credits that are required to be taken by all undergraduate education college students at the Jakarta State University who prepare their collegstudentsnt to become professional educators. As a provision for college students to have a conceptual task as educators, the two courses are needed. Furthermore, in terms of implementing the theory, first, follow microteaching. The implementation of microteaching is an effort that is oriented towards building and improving the teaching profession through training in basic teaching skills in small groups. The aim is to apply the principles of learning in teaching and learning activities as a whole and integrated. When prospective PKM participants, follow microteaching. 
PKM participants get provisions in carrying out teaching practices. The provision of microteaching aims to enable PKM participants to adopt when teaching practice. Moreover, PKM participants have obtained a theory in the Basic Education Course. Furthermore, observation activities were conducted by PKM participants, this implementation was carried out in the PKM implementation school. Starting from observing the school environment, getting to know the teaching staff, and paying attention to the teaching tutor teacher. In this adaptation stage, it can be seen that the activities of the PKM Program have a continuous procedure.

Second, the achievement of this objective function regulates the UPT PPL as a system with PKM participants as the personality subsystem in implementing the PKM Program and partner schools as stakeholders. The function of the PKM Program has the purpose of its implementation. Good teaching practices and non-teaching practices. This goal is the achievement of the PKM Program in general, namely to train PKM college students to be responsible in carrying out tasks as prospective teachers who can develop RPP along with the completeness of learning tools and the ability to carry out learning. This teaching practice training ends with the PKM assessment by the mentor, which is an authentic and good assessment of authenticity. While the purpose of non-teaching activities is so that PKM college students can practice nonteaching skills properly and correctly. From the evaluation results, it can be seen that this process is by the program.

Third, the integrity function shows the need to guarantee that sufficient emotional ties and produce solidarity and willingness to cooperate are developed and maintained. In the PKM program, the integrity function is carried out between the UPT PPL, the PKM faculty coordinator, the supervisor lecturer, the PKM participants as the UNJ party, and the tutor teacher, the teacher council, the principal as the school party. In integrity, the PKM program is needed in its implementation to achieve the goals of the program. From the results of the research assessment, it can be seen that the integrity between the UNJ and the Mitra School is well established in the medium category. This can be seen from the findings of the previous findings. That the intensity of the presence of the supervisor lecturer is expected to be further improved. To maintain sustainable collaboration between UNJ and the PKM Program Partners School.

Fourth, the latent pattern maintenance / latent maintenance pattern is maintained by PKM participants as a PKM system subculture and as a basic principle of the program's objectives. This latent function is as a provision of experience, professional teacher candidates who have gained experience from the PKM Program. From several stages of preparation, implementation, until the end of the PKM Program. In essence, the components that support the implementation of the PKM Program maintain a pattern of relations with the established aspects of the rules (in the PKM handbook) will result in significant achievement. Also a latent function, in this case, was linked to the sustainability collaboration between UNJ and PKM Partner Schools. As an educational institution, cooperation in this program is needed. This relates to the quality of education in the future. In this case to prepare professional teacher candidates. So that in the latent function here, it can be said to have happened and functions properly.

The relationshimeetstween Talcott Parsons's functional requirements is a continuous mutual influence. If on one of these requirements there is a problem, there will be a problem and the objective of the PKM Program is not appropriate. As stated above that the overall requirements of AGIL refer to the requirements for coordinating and creating the whole between the parts in the implementation of the PKM Program. 
Thus the components in the implementation of the PKM Program, each work independently, but are integrated to realize the integrity and sustainability of the overall PKM Program system. In this case, the PKM Program on functional requirements has run well. This can be seen from the components evaluated and the results show a good category so that the PKM Program can be maintained.

To answer the problem of this research, each aspect between the summative evaluation of tutors and supervisors who have been processed is then analyzed. To determine the level of effectiveness of the implementation of the Teaching Skills Program through Glickman quadrant analysis. The quadrant analysis used can illustrate some of the effectiveness of the teaching skills program implementation as follows:

Table 1: Summative Evaluation Results for Supervisors and Summative Evaluation Results for Civil Teachers

\begin{tabular}{|c|c|c|c|c|c|c|c|c|c|c|c|c|c|c|c|c|c|}
\hline \multicolumn{3}{|c|}{$\begin{array}{l}\text { Summative } \\
\text { Supervisors }\end{array}$} & \multicolumn{5}{|c|}{ Evaluation Results for } & \multicolumn{6}{|c|}{$\begin{array}{l}\text { Summative Evaluation } \\
\text { Civil Teachers }\end{array}$} & \multicolumn{4}{|c|}{ Results for } \\
\hline - & - & $+\quad+$ & + & + & $\begin{array}{ll}-\quad+\end{array}$ & - & + & + & & + & + & + & - & - & - & & - \\
\hline+ & + & + & + & + & - & + & - & + & - & + & + & + & - & & + & - & + \\
\hline - & - & + & + & - & + & - & - & + & + & + & + & - & + & + & + & - & - \\
\hline+ & + & + & - & + & + & + & - & + & + & - & + & + & + & + & + & - & - \\
\hline+ & + & + & + & + & + & - & - & + & - & + & + & + & + & - & + & - & + \\
\hline - & - & + & - & - & + & - & + & - & + & + & + & + & + & - & - & + & + \\
\hline - & - & - & - & + & - & + & + & + & - & - & + & + & - & + & + & - & + \\
\hline+ & + & + & - & - & - & - & + & - & + & - & - & - & + & + & - & + & + \\
\hline - & - & - & - & + & + & + & + & - & - & + & - & + & - & + & - & + & - \\
\hline+ & + & + & - & - & - & + & + & - & + & + & - & - & - & - & + & + & + \\
\hline+ & + & - & + & + & + & - & - & - & - & - & + & + & + & + & + & - & - \\
\hline+ & + & + & + & + & + & - & + & - & + & + & - & + & - & + & - & + & - \\
\hline+ & + & - & + & + & - & - & - & - & - & - & + & + & + & + & - & - & - \\
\hline - & - & - & + & + & + & - & + & + & - & - & + & + & + & - & - & - & + \\
\hline+ & + & + & + & + & + & - & - & + & + & - & + & + & + & & - & - & + \\
\hline+ & + & + & + & + & + & - & - & + & - & - & + & + & + & + & - & - & + \\
\hline+ & + & - & - & + & - & - & - & + & + & + & + & + & - & - & - & + & + \\
\hline+ & - & + & - & - & - & - & - & + & + & + & - & & - & & & - & + \\
\hline - & + & + & + & - & + & - & - & - & + & - & + & - & + & - & + & + & - \\
\hline+ & + & + & + & + & - & - & - & + & - & + & - & + & + & + & + & - & + \\
\hline+ & + & + & + & + & + & + & + & & - & - & + & + & + & - & + & + & - \\
\hline & - & $\begin{array}{ll}- & - \\
\end{array}$ & - & & & & & & & - & - & & & & & & \\
\hline \multicolumn{5}{|c|}{ Positive Amount } & \multicolumn{3}{|l|}{123} & \multicolumn{6}{|c|}{ Positive Amount } & \multicolumn{4}{|c|}{113} \\
\hline \multicolumn{5}{|c|}{ Negative Amount } & \multicolumn{3}{|c|}{91} & \multicolumn{6}{|c|}{ Negative Amount } & \multicolumn{4}{|c|}{101} \\
\hline \multicolumn{5}{|c|}{ Evaluation Decision } & \multicolumn{3}{|c|}{$\begin{array}{l}\text { Good } \\
\text { category }\end{array}$} & \multicolumn{6}{|c|}{ Evaluation Decision } & \multicolumn{4}{|c|}{$\begin{array}{l}\text { Good } \\
\text { category }\end{array}$} \\
\hline
\end{tabular}

The results of the summative evaluation analysis of the supervisors found that the effectiveness of the implementation of Teaching Skills Practices in the Jakarta State University Educational Development Institute in the 106th semester of 2016/2017 was classified as effective in the good category with a positive number of 123 while the negative number 91. Based on existing data we can see for the Summative evaluation of tutor teachers showed a positive frequency of 123 respondents or $59 \%$ and a negative frequency of 91 respondents or $41 \%$. So for summative evaluation, the supervisor is in a positive position, namely the good category. This means that in the summative evaluation of the supervisors related to the performance of the supervisor in the implementation of the meets PKM program, seen from the evaluation results according to the $T$ score analysis from Glickman where the total positive score is greater than the number of negative frequencies. Whereas for the quality of graduates the positive and negative frequencies are as large as $50 \%$ so that for summative evaluation of the supervisor lecturers included in the positively stated category in the good category.

While the results of the analysis found a summative evaluation of the tutor teacher that the effectiveness of the implementation of Teaching Skills Practices at the 
Jakarta State University Educational Development Institute in the 106th semester of $2016 / 2017$ was effective in the good category with a positive number 113 while the negative number 101. Based on the existing data we can see for summative evaluation of tutor teachers showed a positive frequency of 113 respondents or $52 \%$ and a negative frequency of 101 respondents or $48 \%$. So for summative evaluation of the tutor teacher is in a positive position namely good category. Meaning In the summative evaluation of the tutor's teacher regarding the performance of the tutor teacher in the implementation of the PKM Program, it was seen from the evaluation results according to the T score analysis from Glickman where the total positive score was greater than the number of negative frequencies. Whereas for the quality of graduates the positive and negative frequencies are as large as $50 \%$ so that for summative evaluation of tutor teachers included in the positively stated category in the good category.

\section{B. Summative Evaluation}

Use of the PKM Program for PKM participants, Partner Schools, and Jakarta State University in preparing a new generation of teacher and education personnel. Moreover, the PKM Program is the estuary of all the educational programs that have been acquired during college, training courses to apply various knowledge, skills, and attitudes, and the formation of professional and reliable teachers and education personnel. Sources of information are obtained from the physical data of the PKM Program exam results and are supported by the results of field interviews.

The implementation of the PKM Program is carried out by what has been programmed, from the university level to the PKM Partner School. It was found that the results of PKM implementation were in line with expectations, where PKM participants had completed the PKM Program with moderate results namely a high category with all participants passing all. This identifies, that the implementation of the PKM Program is by the procedures starting from the preparation and the end of the implementation. So this program can be continued by maintaining its implementation by the procedures in the PKM manual. For the PKM Program to become a program that provides results that are in line with its objectives, it is to prepare a new generation of teacher and education personnel. These results are found in the long process, namely 1 (one) semester at the school where they carry out PKM. The value of the PKM Program participants is found from the process to the end of the implementation, the value of the tutor teacher and the supervisor.

\section{CONCLUSIONS AND RECOMMENDATIONS \\ Conclusion}

Conclusions from the results obtained from the results of this evaluation study are related to the formulation of the problem regarding the implementation of the Teaching Practice Program (PKM/ Praktik Keterampilan Mengajar) Semester 106 of 2016/2017, as follows:

1. Formative Components

Evaluation of the formative stage components is: (a) Technical preparation (b) Registration of the PKM Program (c) Requirements for PKM participant college student (d) debriefing and release (e) Implementation of Teaching Skills Practices in the Partner School.

Analyzing from the results of the formative stage evaluation in the preparation and implementation of the 106 PKM Teaching Skills Practice Program, according to Djaali and Mulyono stated that evaluation refers more to activities take activities to gather information about the workings of something than the information is to determine the right alternatives in making decisions. Further formative evaluation is to assess ongoing project activities and provide information to monitor and improve the program. 
This is done at several points in the process of a program and its activities. From the evaluation results, it can be seen that the PKM Program process runs according to the existing guidelines. So that the existence of the PKM Program can be maintained. While the process of the relationship between the lecturer and the tutor teacher needs to be improved. This can be seen from the results of the study found that the intensity of the supervisor is in the medium category, to guide college students in the Partner School and discuss with the tutor teacher.

2. Summative Components

The focus of the summative component evaluation is based on the results of the assessment provided by the tutor teacher and supervisor. The results found from the PKM participants' final exams for one semester were at the PKM Partner School which ended with a final examination.

Summative evaluation at the end of the PKM program shows in the high category, this is based on the value of PKM participants at least B given by the tutor teacher and supervisor from the final exam. The criteria that have been determined from the PKM guidebook, so that it becomes the basis of the conclusion that this program is in line with what is expected and the reality of the PKM 106 program and the end.

\section{Recommendation}

Based on the conclusions of the assessment results that have been presented, efforts can be recommended to improve the implementation of the Teaching Skills Practice Program (PKM).

1. Formative Components

Although the evaluation results of the formative components in the moderate category tend to be high. This is based on the general conclusion of the implementation of the PKM Program, where the implementation of this program is by the implementation manual. So that it can be concluded that, but changes in the internal and external environment have a strong influence to be anticipated so that efforts to maintain every aspect, especially the role of the leadership of the UPT PPL / PKL needs to be considered so that the change of leadership will not weaken the implementation of the PKM Program. It was recommended to the Jakarta State University to support in the form of socialization of the PKM Program to the Partner School to provide synergy in the form of cooperation in the implementation of this program. By paying attention to the needs of the implementation of the PKM Program, especially related to the intensity of the form of cooperation related to the socialization of the PKM Program.

2. Summative Components

Based on the evaluation of the summative component of the 106 Teaching Skills Practice Program, it is in the high category. However, this can change in the next implementation. But the results can be maintained in this high category, namely by continuing to prepare PKM participants. Starting from the preparation of deepening the material in the Subjects of Basic Education Courses (MKDK) and Microteaching learning which is a step in fostering learning competencies. Microteaching is an effort to help prospective teachers to practice 4 professional teacher competencies in preparation for entering the Teaching Skills Practices (PKM). Through careful preparation, then the implementation of the PKM Program will then produce the expected results, namely, the PKM participants graduated entirely.

\section{REFERENCES}

Anderson, Scarvia B., Ball, Samuel., and Murphy, Richard T., 1978. The Profession and Practice of Program Evaluation. San Fransisco: Jossy-Bass Publisher. 
Arikunto, Suharsimi., 1988. Penilaian Program Pendidikan, Departemen pendidikan dan Kebudayaan Direktorat jendral Pendidikan Tinggi. Jakarta: Pengembangan Lembaga Pendidikan Tinggi.

Arikunto, Suharsimi., dan Jabar, Cepi Safruddin Abdul., 2009. Evaluasi Program Pendidikan. Jakarta: Bumi Aksara.

Astuti, Ni Wyn Widi., Suhandana I G. A., dan Dantes, N., 2013. Studi Evaluasi Efektivitas Pelaksanaan Praktik Pengalaman Lapangan (PPL) Mahasiswa Fakultas Pendidikan Olahraga Dan Kesehatan (FPOK) IKIP PGRI Bali Tahun 2012," Journal Program Pascasarjana Universitas Pendidikan Ganesha, Volume 4 Tahun, 2013.

Buku Pedoman Praktik Keterampilan Mengajar (PKM)., $2016 . \quad$ Lembaga Pengembangan Pendidikan Universitas Negeri Jakarta.

Creswell, John W., 2016. Pendekatan Kualitatif, Kuantitatif, dan Campuran. Yogyakarta: Pustaka Pelajar.

Dart Jessica, and Petheram R.J., 1998. Review of Evaluation in Agricultural Extension. Macquarie Street: Rural Industries Research and Development Corporation.

Dart, Jessica., and R John Petheram., 1998. "Review of Evaluation in Agricultural Extension." Rural Industries Research and Development Corporation.

Djaali., Pudji, Mulyono., dan Ramli., 2002. Pengukuran dalam Bidang Pendidikan. Jakarta: PPs UNJ.

Frechtling, Joy, and Westat., 2010. "The 2002 User-Friendly Handbook For Project Evaluation." Division of Research and Learning in Formal and Informal Settings National Science Foundation, 2010.

http://shareit4us.blogspot.co.id/2010/06/model-evaluasi-program.html (Diakses 30 Oktober 2016).

http://unj.ac.id/lpp/ (Diakses 28 November 2016).

Mabasa, Layne Thomas., 2013. "A responsive evaluation approach in evaluating the safe schools and the child-friendly school's programs in the Limpopo province." Dissertation, Stellenbosch University.

Mulyadi. Suprayekti. dan Fathia Fairuza Hanum., 2015. Evaluasi Program. Jakarta: Lembaga Pengembangan Pendidikan UNJ.

Panca, I Putu., 2015. "Sistem Evaluasi Dan Kesiapan Pelaksanaan PPL- Real Di Sekolah Mitra”. JPI-Jurnal Pendidikan Indonesia, Volume. 4, No.2, 2015.

Stufflebeam Daniel L., and Shinkfield, Antony J., 1989. Systematic Evaluation: A SelfInstruction Guide to Theory and Practice. Boston: Kluwer Nijhoff Publishing.

Stufflebeam, Daniel L., 2003. The CIPP Model Evaluation. Paper Presented at the 2003 Annual Conference of the Oregon Program Evaluators Network, Portland, Oregon.

Sugiyono., 2009. Penelitian Kuantitatif, Kualitatif dan $R$ \& D. Bandung: PT Alfabeta.

Tayibnapis, Farida Yusuf., 2018. Evaluasi Program dan Instrumen Evaluasi untuk Program Pendidikan dan Penelitian. Jakarta: Rineka Cipta.

Welty, Gordon., 2008. "Formative Evaluation in the ADDIE Model." Journal of GXP Compliance, Volume 12, Number 4, Summer 2008.

Wholey, Joseph S., Hatry, Harry P., and Newcomer, Kathryn E., 2010. Handbook Of Practical Program Evaluation. United States Of America: Jossey-Bass.

Wilde Judith., and Sockey, Suzanne., 1995. Evaluation Handbook. New Mexico: New Mexico Highlands University.

Wirawan., 2011. Evaluasi: Teori, Metode, Standar, Aplikasi, dan Profesi. Jakarta: Raja Grafindo Persada 